\title{
NEW RECORDS OR RECURRENCES OF RARE FISHES FROM EASTERN AUSTRALIA.
}

By Edgar R. Waite, F.L.S., Zoologist.

(Plates xli. - xliii.)

IN the present paper I record three fishes not previously recognised from New South Wales. Food is the chief matter dealt with under Cetorhinus maximus, Gunner; a short description is given of a specimen of Tetragonurus cuvieri, Risso, taken in our waters; and Pomadasis hasta, Cuvier and Valenciennes, is recorded from an example secured in the Richmond River.

A catch of three specimens of Chimcera ogilbyi, Waite, is recorded, and descriptions and tigures each of Prototroctes marcena, Günther, and Harpe vulpina, Richardson, are furnished, both species being very rare in our waters.

Finally, a description is published of Valenciennia longipinnis, Bennett, from an example taken on the Barrier Reef, Queensland. The nature of the original figure suggested the advisability of re-illustrating the species. I have, therefore, taken great pains with the drawing now offered.

Cetorhinus maximus, Gunner.

Squalus maximus, Gunner, Trondhjem. Selskabskr., iii., 1765, p. 33.

To Mr. J. A. Boyd, of Eden, we owe the privilege of first recording this interesting Shark for New South Wales. In May, 1901, this gentleman forwarded a piece of "baleen," which I recognised as portion of the gill of Cetorhinus, the shark having been taken in Twofold Bay. On the 14th August following, another Basking Shark entered the bay, and was shot. Its identity was recognised by Mr. Boyd, who watches our. interests in this locality, and the specimen was at once forwarded to Sydney. It proved to be a young male, ten and a half feet in length.

The stomach and intestines were found to be charged with food, the whole forming a gelatinous-like substance of a bright salmon colour. Mr. Thomas Whitelegge, to whom I submitted a sample, pronounces it to be composed of the Anomurous Crustacean Munida subrugosa, White, commonly called "Whale-food," a term applied to pelagic assemblies of Pteropods or Crustaceans. 